\title{
Griceren adibide galdua. Esanahi naturalari buruzko probaren gabeziak
}

\author{
Grice's missing example. \\ The flaws of the test for natural meaning
}

KePA KORTA*, MadDI MENDIBIL ${ }^{\&}$

Euskal Herriko Unibertsitatea (UPV/EHU)

LABURPENA. Gricek «Esanahia» (2007 [1957]) artikuluaren hasieran ematen dituen hiru adibideetatik bigarrenarekin gertaera bitxia topatu dugu. Esanahi naturalaren adibide nagusietako baten gisa aurkezten du, baina ez du inoiz ezertarako erabiltzen; ez artikulu horretan, ezta gai berari eskaini zion «Meaning Revisited»en (1982) ere. Gainera, adibideak ez du betetzen esanahi naturalarentzat Gricek ezartzen dituen irizpideetan lehena eta garrantzitsuena: faktibotasuna. Adibide hori «Esanahia»n sartzea, beraz, Griceren hutsegitea da; guk dakigula, artikuluak izandako berrargitalpen ugarietan sekula konpondu ez den hutsegitea. Nahastea agian, baina garrantzi historikoaz aparte, garrantzi kontzeptuala ere izan dezakeena.

GAKO-HITZAK: Grice; esanahi naturala eta ez-naturala; irizpideak; faktibotasuna; probabilitate-gradua.

ABSTRACT. We found a curious fact about the second of the three examples at the very beginning of Grice's «Meaning» (1957). He introduces it as an example of natural meaning, but he never uses it again, neither in that paper nor in "Meaning Revisited" (1982), devoted to the same topic. Furthermore, the example doesn't meet the first and foremost criterion that Grice sets for natural meaning: factivity. The insertion of that example in "Meaning» is an error, we contend; an error that was never corrected in the multiple editions of the paper; a mistake that, besides its historic importance, might have conceptual relevance too.

KEYWORDS: Grice; natural and non-natural meaning; criteria; factivity; probability degree.

\& Bi egileok gure esker ona adierazi nahi diegu GOGOAren bi ebaluatzaile anonimoei, beren iruzkin eta iradokizun baliotsuengatik. Lehen egileak estimatzen ditu Espainiako MINECOren ((FFI2015-63719-P (MINECO/FEDER, UE)) eta Eusko Jaurlaritzaren (IT1032-16) ikerketarako dirulaguntza bana ere.

\footnotetext{
* Harremanetan jartzeko / Corresponding author: Kepa Korta. ILCLI. Euskal Herriko Unibertsitatea (UPV/EHU). Carlos Santamaria Zentroa. Elhuyar plaza, 2 (20018 Donostia) - kepa.korta@ehu.eus - https://orcid.org/0000-0003-3002-5607

Nola aipatu / How to cite: Korta, Kepa; Mendibil, Maddi (2019). "Griceren adibide galdua. Esanahi naturalari buruzko probaren gabeziak», Gogoa, 19, 35-53. (https://doi.org/10.1387/gogoa.21095).

Jasoa: 2019-V-21. Onartua: 2019-IX-9. Aurrena online argitaratua: 2019-IX-12.

ISSN 1577-9424 - elSSN 2444-3573 / (c) 2019 UPV/EHU
}

(c) (i) Lan hau Creative Commons Aitortu 4.0 Nazioartekoaren

lizentziapean dago 
Kepa Korta, Maddi MendibiL

\section{Sarrera}

Paul Gricek hiru adibideokin hasten du «Esanahia» (2007 [1957]) artikulua:

— «Orban horiek elgorria esan nahi dute (zuten).»

— «Orban horiek niretzat ez zuten ezer esan nahi, baina medikuarentzat elgorria esan nahi zuten.»

— «Azken aurrekontuak urte gogorra izango dugula esan nahi du.»

Hiru adibideok esanahi naturalaren adibide gisa ematen ditu, eta esanahi mota horren ezaugarritzat proposatzen dituen bost baldintzak betetzen dituztela esaten du.

Hala ere, gertaera harrigarri batekin egin dugu topo. Bigarren adibideak ez ditu baldintza horiek guztiak betetzen, eta baldintza garrantzitsuenean huts egiten du. Beraz, zergatik sartzen du adibide hori Gricek? Nola liteke ez Grice bera ez Philosophical Review aldizkariaren argitaratzaileak ere hutsegite horretaz ohartu ez izana, 1957an? 1989an bere lanen bilduman berrargitaratu zuenean ere ez al zion inork akatsaren berri eman? Ezetz ematen du. Akatsak bere horretan jarraitu du eta, guk dakigula, inork ez du seinalatu.

Bestalde, lanaren lehen lerroetan aurkeztu ondoren, Gricek ez du adibidea behin ere erabiltzen baldintzen eztabaidan; beste bi adibideak dira behin eta berriz baldintza bakoitza betetzen dutela esateko erabiltzen dituenak; bigarrena ez. Hori izan daiteke akatsaren kausa: adibidea idatzi ondoren, behin ere erabiltzen ez duenez, ez da ohartzen ez duela balio. Ez dakigu kasualitatea ote den, hain justu, baldintzak betetzen ez dituen adibidea ahaztu izana. Dena den, nahastea edo deskuidua bikoitza da: ez du adibidea erabiltzen, batetik, eta adibideak ez du betetzen ematen dituen baldintzetako garrantzitsuena, bestetik. Lanak izan dituen ehunka irakurleek ez dute adibidea erabili eta ez dute hutsegitean erreparatu. Edota, akaso, konturatu badira ere, txikiegia iruditu zitzaien lehen Griceri berari pribatuan jakinarazteko, huskeria iruditu zaie gero publiko egiteko.

Nolanahi ere den, akatsa hor dago eta, egiari zor, seinalatzea merezi du. Gainera, uste baino garrantzitsuagoa izan daiteke akaso. Baliteke akats hori gabezia handiago baten adierazle izatea. Baliteke esanahi naturalaren eta eznaturalaren arteko bereizketa ez izatea Gricek aurkeztu bezain argia. Hori ere saiatuko gara argitzen lan honetan.

Lanaren egitura honako hau da. Hasteko, «Esanahia» artikuluaren nondik norakoak aurkeztu ditugu laburki hurrengo atalean. 3. atalean esanahi naturalaren eta ez-naturalaren bereizketa egiteko ematen dituen adibide sailak eta haien ezaugarriak azaldu ditugu. 4. eta 5. ataletan, Gricek egin- 
kizun utzitakoari heldu diogu: (ii) adibidea proposatutako testen argitan aztertu dugu, eta erakutsi dugu, 4. atalean, aplika dakiokeen neurrian, ez duela faktibotasuna betetzen, eta, 5. atalean, emaitza desberdinak dauzkala beste lau probei dagokienez. Hurrengo bi ataletan, Griceren deskuiduaren azalpenen bat asmatzen saiatu gara, lehenik, eta, bukatzeko, aurkikuntzaren garrantzia balioetsi dugu. Azkenik, ondorioak atera ditugu labur, 8. atalean.

\section{2. «Esanahia»}

Griceren «Logic and Conversation» da, dudarik gabe, Griceren lanik garrantzitsuena (1967an aurkeztu zuen arren, 1975ean argitaratu zutena). Itzela izan da (eta da) hizkuntzalaritzan eta filosofian - hizkuntzaren filosofian, bereziki - izan duen (eta oraindik duen) eragina. Bigarren artikulu garrantzitsuena ia hogei urte lehenago argitaratutako «Esanahia» (2007 [1957]) da. Artikulu laburra da eta, nolabait esatearren, programatikoa; proiektu baten oinarria ezarri eta aurrera egiteko nondik norako orokorrak zirriborratzen dituena. Bertan aurkezten duen proiektua handia da, nolanahi ere: esanahi nozioaren oinarri metafisikoa aurkitzea du helburu, nozio horren aldaera nagusien azalpen bateratua ematea. Hitzek eta horiekin osatzen ditugun euskarazko perpausek, esate baterako, esanahia daukate, euskarazko hitzak eta perpausak izatetik datorkiena. Euskal hiztunok, euskarazko perpausak erabiliz, hainbat gauza esan nahi izaten ditugu normalean. Eta testuinguru jakinetan esanahi aberatsagoak edo zehatzagoak adierazten ditugu, euskarazko perpausaren esanahi «normaletik» harago doazenak maiz; esanahi horrez guztiz bestelakoak diren esanahiak, batzuetan. Are gehiago, euskarazko nahiz beste edozein hizkuntzatako hitzik nahiz perpausik erabili gabe ere, esanahiak komunikatzeko gai gara.

Esanahi ez-natural gisa sailkatzen ditu Gricek esanahi mota horiek guztiak «Esanahia»n. Eta, bere ustez, horien artean kontzeptualki oinarrizkoa da esaldi jakin batekin hiztun jakin batek esan nahi duena edo, labur beharrez, hiztunaren esanahia (speaker's meaning). Unean uneko hiztunaren esanahia da funtsezko esanahi mota. Hiztunak normalean esan nahi duenak unean unekoa izango du oinarri. Hiztun partikularretik harago, hizkuntz komunitateak normalean esan nahi duena gero etorriko da analisi kontzeptualean. Eta horrela hizkuntza jakin bateko perpausek eta hitzek testuinguru jakinetik kanpo, denbora jakin batetik kanpo, esan nahi dutenera iritsi arte. Esanahi ez-naturalen harreman kontzeptual hierarkikoaren azalpena zirriborratu besterik ez du egiten Gricek (ikus 1. taula). Artikuluaren zatirik handiena lehen eta bigarren mailen arteko erlazioari eskaintzen dio; alegia, hiztunaren asmoaren eta esanahiaren azalpenari. 
Kepa Korta, Maddi MendibiL

\section{1. taula}

Esanahiaren analisi metafisikoaren ordena kontzeptuala

Hiztunaren M-asmoa
$\downarrow$
Hiztunaren esaldiaren esanahia
$\downarrow$
Hiztunaren esaldi-tipoaren esanahi ohikoa
$\downarrow$
$\downarrow$
Esaldi-tipoaren esanahi ohikoa hizkuntz komunitatean
Hitz eta perpausen esanahi konbentzionala

Hiztunaren esanahia ez da bakarrik hitzen bidezkoa; hizkuntzarik gabeko ekintzek ere esanahi ez-naturala izan dezakete. Hori da, hain zuzen, «hiztuna»ren esanahirik oinarrizkoena. ${ }^{1}$ Eta esanahi nozio hau hiztunaren - hots, agentearen- egoera psikologikoetara ekar daiteke, hiztunaren asmo berezi baten arabera, M-asmoaren (M-intention) arabera, definituz. Horixe da Griceren artikulu honen ekarpenik ezagunena: semantikako nozio nagusia, esanahia, agenteak ekintza bat egitean dauzkan nozio psikologikoetan definitzea. Horrek eragin zuen eztabaidarik biziena «Esanahia»ren inguruan, eta bigarren maila batean geratu ziren Gricek iradokitako hainbat eta hainbat puntu, hala nola, hiztunaren esanahiak perpausaren esanahiarekin duen harremana edo esanahi naturalaren karakterizazioa. Normala izan liteke, Gricek berak lan honetan puntu hauek iradoki besterik ez baitu egiten. Gero landu zituen gehiago «Uttererer's Meaning, Sentence Meaning, and Word-Meaning» (1968) artikuluan eta beste batzuetan. Esanahi naturalaren analisia, aldiz, ez zuen garatu Gricek, eta inor gutxik egin du gerora. Denkel (1992) da ezagutzen dugun salbuespen bakarretakoa.

Hori horrela, «Esanahia»ren beste alderdi bati erreparatu nahi diogu guk lan honetan. Hizkuntza naturalaren eztabaidan, guk dakigunez behintzat, oharkabean igaro den kontu bati. Esan bezala, esanahi naturalaz ari dela, oker bat egiten du Gricek; oker nabarmena, artikuluaren hasieran berean. Eta, guk dakigula, inork ez du oker hori seinalatu; ez dakigu zergatik. Kontua da inork ez duela hau lehenago esan, edo guk behintzat ez dugula inoiz lehe-

\footnotetext{
1 «Esanahia» artikulu osoan zehar, beraz, eta baita lan honetxetan ere, zentzu zabal horretan ulertu behar dira «hiztun» (speaker), «esale» (utterer) eta «esaldi» (utterance); agente gisa lehenengo biak, eta ekintza gisa azkena.
} 
nago entzun edo irakurri. Eta guk esan egingo dugu: Gricek akats nabarmena egiten du «Esanahia»ren lehen lerroetan, eta isilean pasatu da. Gricek berak ez zuen zuzendu artikuluaren bertsio ezberdinetan edo gaiari buruz berriz aritu zenean. Beste inork ere ez du zuzendu, Griceren «Esanahia»z aritzean.

Akatsa zein den argitzeko, «Esanahia»ren lehen bi orrialdeak azaldu behar ditugu, lehenbizi, labur bada ere.

\section{Esanahi naturala eta ez-naturala}

«Esanahia» horrelaxe hasten da:

Gogoan har perpausok:

i. «Orban horiek elgorria esan nahi dute (zuten).»

ii. «Orban horiek niretzat ez zuten ezer esan nahi, baina medikuarentzat elgorria esan nahi zuten.»

iii. «Azken aurrekontuak urte gogorra izango dugula esan nahi du.» (Grice 2007 [1957]: 145) ${ }^{2}$

Eta beste ezer gehitu gabe, zenbakitutako bost paragrafo datoz, goiko adibide horiek dauzkaten hainbat ezaugarri azaltzen dituztenak. Honako hauexek dira, hitzez hitz:

(1) Ezin dut esan «Orban horiek elgorria esan nahi zuten, baina ez zeukan elgorririk», eta ezin dut esan "Azken aurrekontuak urte gogorra izango dugula esan nahi du, baina ez dugu izango». Alegia, goiko kasuen gisakoetan, $x \mathrm{k} p$ esan nahi zuenek eta $x \mathrm{k} p$ esan nahi $d u \mathrm{k} p$ inplikatzen dute.

(2) Ezin dut argudiorik osatu «Orban horiek elgorria esan nahi dute (zuten)»etik «orban horiek esan nahi dutena (zutena)»ri buruzko inolako ondoriotara iristeko; adibidez, ezin dezaket esan «orban hauek esan nahi zutena zen hark elgorria zuela». Era berean, azken aurrekontuari buruzko goiko baiezpenetik ezin dut ondorioztatu «Azken aurrekontuak esan nahi duena da urte gogorra izango dugula».

(3) Ezin dut argudiorik osatu «Orban horiek elgorria esan nahi dute»tik norbaitek orban horien bitartez hau-ta-hau esan nahi zuen moduko

\footnotetext{
2 Adibideen zenbakiak gureak dira. Aldaketa batzuekin, Kortaren euskarazko itzulpena dakargu hona (Korta 2007: 145-55); eta, Gogoaren irizpideei jarraiki, oin-oharretan emango dugun aipamenen ingelesezko bertsioa Kortak erabilitakoa da (1989koa):

«Those spots mean (meant) measles.»

«Those spots didn't mean anything to me, but to the doctor they meant measles.»

«The recent budget means that we shall have a hard year.» (Grice 1989 [1957]: 213).
} 
inolako ondoriotara iristeko. Mutatis mutandis, gauza bera gertatzen da azken aurrekontuari buruzko perpausarekin.

(4) Goiko adibideetatik bat ere ezin da berregin «esan nahi» aditzaren aurretik komatxo arteko perpaus edo adierazpen bat daramala. Honela, «Orban horiek elgorria esan nahi zuten» ezin da birformulatu «Orban horiek 'elgorria' esan nahi zuten» edo «Orban horiek 'elgorria duela' esan nahi zuten» gisan.

(5) Bestalde, adibide hauek guztiak gutxi gorabehera berregin daitezke «...-elako gertakaria» adierazpena sartuz; adibidez, «Orban horiek zituelako gertakariak elgorria zuela esan nahi zuen» eta «Azken aurrekontua zen bezalakoa zelako gertakariak urte gogorra izango genuela esan nahi zuen» (Grice 2007 [1957]: 145-6). ${ }^{3}$

Gricek (i)-(iii) perpausetan azaltzen diren «esan nahi» horiek guztiak erabiltzen diren zentzuari «zentzu natural» esango dio aurrerago, eta «zentzu eznatural» esango dionarekin alderatzeko erabiltzen du. Zentzu ez-natural horren adibide gisa, honako bi perpausok eskaintzen ditu:

iv. «(Autobuseko) txirrinaren hiru joaldi horiek autobusa beteta dagoela esan nahi dute.»

v. «Ohar horrek, 'Smithek ezin zuen segi bere arazo eta liskarrik gabe', Smithek bere emaztea behar-beharrezkoa zuela esan nahi zuen.» (Grice 2007 [1957]: 146). ${ }^{4}$

Eta, beste ezer emendatu gabe, zenbakitutako beste bost paragrafo ematen ditu bi perpausok dauzkaten hainbat ezaugarri azaltzeko. Honako hauek:

3 (1) I cannot say, «Those spots meant measles, but he hadn't got measles,» and I cannot say, «The recent budget means that we shall have a hard year, but we shan't have.» That is to say, in cases like the above, $x$ meant that $p$ and $x$ means that $p$ entail $p$.

(2) I cannot argue from «Those spots mean (meant) measles» to any conclusion about «what is (was) meant by those spots»; for example, I am not entitled to say, «What was meant by those spots was that he had measles.» Equally I cannot draw from the statement about the recent budget the conclusion «What is meant by the recent budget is that we shall have a hard year.»

(3) I cannot argue from «Those spots meant measles» to any conclusion to the effect that somebody or other meant by those spots so-and-so. Mutatis mutandis, the same is true of the sentence about the recent budget.

(4) For none of the above examples can a restatement be found in which the verb «mean» is followed by a sentence or phrase in inverted commas. Thus «Those spots meant measles» cannot be reformulated as «Those spots meant 'measles'» or as «Those spots meant 'he has measles.'»

(5) On the other hand, for all these examples an approximate restatement can be found beginning with the phrase «The fact that . ..»; for example, «The fact that he had those spots meant that he had measles» and «The fact that the recent budget was as it was means that we shall have a hard year» (Grice 1989 [1957]: 213-4).

4 «Those three rings on the bell (of the bus) mean that the bus is full.»

«That remark, 'Smith couldn't get on without his trouble and strife,' meant that Smith found his wife indispensable» (Grice 1989 [1957]: 214). 
(1') Hauetako lehena erabil dezaket eta jarraitu esanez «Baina ez dago egiazki beteta — gidaria erratu egin da-»; eta bigarrena erabil dezaket eta jarraitu «Baina Smithek egiazki orain zazpi urte utzi zuen emaztea». Alegia, hemen $x \mathrm{k} p$ esan nahi duk eta $x \mathrm{k} p$ esan nahi zuenek ez dute $p$ inplikatzen.

(2') Lehenengotik egin dezaket argudioa txirrinaren joaldiek «esan nahi dutena (zutena)»ri buruzko baiezpenen bat ondorioztatzeko eta bigarrenetik aipatu komentario horrek «esan nahi duena (zuena)»ri buruzko baiezpenen bat.

(3') Lehenengo perpausetik ondoriozta dezaket norbaitek (hots, gidariak) joaldien bitartez autobusa beteta dagoela esan nahi zuela, edo gutxienez hori esan nahi beharko zukeela, eta antzera argudia dezaket bigarren perpauserako.

(4') Lehenengo perpausa berregin daiteke «esan nahi» aditzaren aurretik komatxoen arteko adierazpen bat daramala, hau da, «Txirrinaren hiru joaldi horiek 'autobusa beteta dago' esan nahi dute». Bigarren perpausa ere berdin.

(5') «Txirrinak hiru aldiz jo duelako gertakariak autobusa beteta dagoela esan nahi du» bezalako perpaus bat ez da lehenengo perpausaren esanahiaren birformulazioa. Biak egiazko izan daitezke, baina ez dute, ezta gutxi gorabehera ere, esanahi bera. (Grice 2007 [1957]: 146). ${ }^{5}$

Ezaugarri hauek aurrekoen aurkakoak dira zuzen-zuzenean. Lehen «ezin dut esan» (1), «ezin dut argudiorik osatu» (2-3), «ezin da berregin» (4) esaten zuen tokian, orain «erabil dezaket» $\left(1^{\prime}\right)$, «egin dezaket argudioa» $\left(2^{\prime}\right)$, «ondoriozta dezaket» $\left(3^{\prime}\right)$, «berregin daiteke» $\left(4^{\prime}\right)$ dio. «Berregin daitezke» (5) zioen tokian, «ez da birformulazioa» $\left(5^{\prime}\right)$ dio orain. Talde bakoitzeko adibide bana

\footnotetext{
5 Paragrafo hauen itzulpenean Griceren zenbakiak pittin bat aldatu ditugu (zenbaki bakoitzari ' gehituta), argitasunaren mesedetan.

(1) I can use the first of these and go on to say, «But it isn't in fact full-the conductor has made a mistake»; and I can use the second and go on, «But in fact Smith deserted her seven years ago.» That is to say, here $x$ means that $p$ and $x$ meant that $p$ do not entail $p$.

(2) I can argue from the first to some statement about «what is (was) meant» by the rings on the bell and from the second to some statement about «what is (was) meant» by the quoted remark.

(3) I can argue from the first sentence to the conclusion that somebody (viz., the conductor) meant, or at any rate should have meant, by the rings that the bus is full, and I can argue analogously for the second sentence.

(4) The first sentence can be restated in a form in which the verb «mean» is followed by a phrase in inverted commas, that is, «Those three rings on the bell mean 'the bus is full.'» So also can the second sentence.

(5) Such a sentence as «The fact that the bell has been rung three times means that the bus is full» is not a restatement of the meaning of the first sentence. Both may be true, but they do not have, even approximately, the same meaning (Grice 1989 [1957]: 214).
} 
hartuta ikus daiteke alderatzearen nondik norakoa. Ezin da esan «Orban horiek elgorria esan nahi zuten, baina ez zeukan elgorririk»; esaldi zentzugabea litzateke, absurdoa. Baina esan daiteke «txirrinaren hiru joaldi horiek autobusa beteta dagoela esan nahi dute» eta jarraitu «baina ez dago egiazki beteta». Eta, antzera, gainerako ezaugarriekin.

Horrela abiatzen du esanahi naturalaren eta ez-naturalaren arteko bereizketa Gricek. (i)-(iii) perpausak esanahi naturalaren adibide argiak izango lirateke, argi asko (1)-(5) ezaugarriak leuzkaketenak; (iv)-(v) perpausak, aldiz, esanahi ez-naturalaren kasu argiak, (1')-(5') ezaugarrien jabe. Edozein bestelako kasuren aurrean gaudela, horrelako perpausetan formulatu, eta esanahi mota baten ala bestearen aurrean gauden erabakitzeko irizpideak lirateke ezaugarri talde horiek.

Gricek «Esanahia» artikuluan aurrerago dioenez, esanahi naturalaren eta ez-naturalaren arteko bereizketa hori hobea dela uste du zeinu naturalaren eta konbentzionalaren artekoa baino. Eta horri buruzko C. L. Stevensonen (1944) azalpena laburki eztabaidatu ondoren, esanahi ez-naturalaren analisiarekin hasten da buru-belarri.

Gure lan honetan, hala ere, esanahi naturala da kontua, lehen ere esan dugunez: ematen dituen adibideak (i-iii) eta esleitzen dizkien (1-5) ezaugarriak. Ezaugarri horiek eztabaidatuko ditugu laburki hurrengo atalean. Baina honezkero azpimarra dezakegu lehen gertaera harrigarria: (ii) adibidea ez da behin ere azaltzen; Gricek ez du behin ere erabiltzen, eta, ondorioz, uler daiteke (1-5) baldintzak betetzen dituela esan gabe doala. (i) eta (iii), biak erabiltzen ditu sistematikoki; (ii) ez. Dena dela, azken honek betetzen dituela egiaztatzea irakurlearentzako ariketa erraz gisa uzten duela uler genezake. Eta egin egin dugu, beraz, ariketa hori.

Ariketa hori egiten hasi eta bigarren gertaera harrigarriarekin egin dugu topo. Lehen baldintza, garrantzitsuena, ez du inolaz ere betetzen (ii) adibideak. Ikus dezagun.

\section{Faktibotasuna}

Esan bezala, (1-5) ezaugarriak —eta horien pareko (1'-5')ak- esanahi natural eta ez-naturalen kasuak bereizteko irizpide edo «test» gisa darabiltza Gricek. Nahikoa garbi dago, bestalde, bost irizpideek ez dutela garrantzi berdina. «Meaning Revisited» (1989 [1982]: 291) lanean horietako bi soilik ekartzen ditu gogora laburki: lehenengoa eta laugarrena. Eta bietan lehenengoari ematen dio garrantzi handiena. Lan berri horretan horrelaxe laburtzen du, gutxi gorabehera, «faktibotasun-testa» esan geniezaiokeen (1)-(1') ezaugarrien emaitza: esanahi ez-naturalaren kasuak ez-faktiboak dira; esanahi naturalaren kasuak, berriz, faktiboak. 
Esanahi naturalaren pare bat adibide berri ere ematen du:

vi. Hodei beltz horiek euria esan nahi dute.

vii. Hodei beltz horiek euria egingo zuela esan nahi zuten. ${ }^{6}$

Eta laburki azaltzen duenez, (vi) edo (vii) esaten duenak onartuko luke euria egingo duela edo euria egin zuela. Edo (1)en terminoetan jarrita baldintza: "Hodei beltz horiek euria egingo duela esan nahi dute'k euria egingo $d u$ inplikatzen du». Horixe besterik ez du esan nahi faktiboak direla esateak.

(1) irizpidea azaldu ostean, (4) aipatzen du Gricek artikuluan eta, horretarako, (vi) adibidea darabil. Adibide berriarekin «Esanahia»n esandakoak berresten ditu: «Hodei beltz horiek euria egingo duela esan nahi dute» perpausa oinarri hartuta, esaten du akatsa litzatekeela Hodei beltz horiek «euria egingo du» esan nahi dutela ondorioztatzea.

Hala ere, ez artikulu batean ez bestean erabiltzen du Gricek (ii) adibidea irizpide nagusiak azaltzean ere. Eta garrantzitsuagoa den kontua: (ii) ez da faktiboa. Ikus dezagun.

«Esanahia»ra itzulita, gogora ekar dezagun berriz adibidea:

ii. Orban horiek niretzat ez zuten ezer esan nahi, baina medikuarentzat elgorria esan nahi zuten.

Griceren nahastea zuzenduz, (1) baldintza adibide hau erabilita berregingo bagenu, horrela hasiko litzateke:

Ezin dut esan «Orban horiek niretzat ez zuten ezer esan nahi, eta (baina) medikuarentzat elgorria esan nahi zuten, baina (eta) ez zeukan elgorririk».

Beste ezer gehitu gabe ere, nahikoa argi dago huts egiten duela, ${ }^{7}$ esan baitaiteke hori inolako kontraesan-arrastorik edo zentzu gabeziarik eragin gabe. Eta arrazoia bilatzeko ere ez dago asko pentsatu beharrik: «niretzat» eta

\footnotetext{
${ }^{6}$ Adibideok zenbakirik gabe eta testuan paragrafo barruan ematen ditu Gricek, komatxoen artean:

«Those black clouds mean rain»... «Those black clouds meant that it would rain». (Grice 1989 [1982]: 291)

7 Perpaus aldrebesa gerta daitekeela onartu arren, gure ustez, argi dago, erabat, ez dagoela hor kontraesanaren inolako arrastorik. Txostengileetako bati, ordea, ez zaio horren argi iruditu, eta gure ziurtasuna leundu dugu pixka bat testuan. Adibidearen lehen zatiak, hala ere, badauka arazo larriago bat ere, aurreraxeago argituko dugunez.
} 
«medikuarentzat» agertzea da giltza. Horiek sartuta adibideak galdu egiten du faktibotasuna. (i) faktiboa da; (ii) ez.

Jarraian, (iii) adibideari aplikatzen dio Gricek testa, eta testaren forma orokorra ematen du:

... eta ezin dut esan «Azken aurrekontuak urte gogorra izango dugula esan nahi du, baina ez dugu izango». Alegia, goiko kasuen gisakoetan, $x \mathrm{k}$ p esan nahi zuenek eta $x \mathrm{k}$ p esan nahi duk $p$ inplikatzen dute. (Grice 2007 [1957]: 145) ${ }^{8}$

Bistan denez, forma orokor hori ezin zaie adibideei bere horretan aplikatu: $x$ ren ordez «orban horiek» edo «aurrekontua» jar daiteke, baina pk proposizio bat eskatzen du, eta, (iii) adibidean proposizio bat badugu ere («urte gogorra izango dugula»), (i) eta (ii)n ez dugu horrelakorik («elgorria» eta «ezer ez»). Beste nolabait ulertu behar dugu, beraz, kontua. Batetik, (1) eta $\left(1^{\prime}\right)$ ko forma orokor hori aplikatu ahal izateko, gutxi gorabehera horrela interpretatu behar dugula ematen du:

$\left(1^{\prime \prime}\right)$ « $x$ gertaerak/ekintzak esan nahi du $p » k p$ inplikatzen du;

eta, ildo berean, (i) eta (ii) adibideak horrela interpretatzea komeni dela:

i'. Pertsona honek orban horiek izateak esan nahi du pertsona honek elgorria daukala (zeukala).

ii'. Pertsona honek orban horiek izateak niretzat ez zuen ezer esan nahi, baina medikuarentzat pertsona horrek elgorria zeukala esan nahi zuen.

Testaren (1") forma orokorra (i')ri aplikatuz argi geratzen da ez duela betetzen, honako hau ez baita zuzena:

- Pertsona honek orban horiek izateak esan nahi du pertsona honek elgorria daukala, baina pertsona honek ez dauka elgorririk.

(ii')ri zuzenean aplikatuta, berriz, horrelako zerbait geratuko litzaiguke:

- Pertsona honek orban horiek izateak niretzat ez zuen ezer esan nahi, eta medikuarentzat pertsona horrek elgorria zeukala esan nahi zuen, baina pertsona horrek ez zeukan elgorririk.

\footnotetext{
8 Jatorrizkoa 2. oin-oharrean.
} 
Testaren aplikazio hau narras samarra gerta daiteke, kasu honetan bi kasuren konjuntzioa baitaukagu. Komeni da, hortaz, adibidea bitan banatzea, testa banaka aplikatzeko:

ii.a. Orban horiek niretzat ez zuten ezer esan nahi.

ii.b. Orban horiek medikuarentzat elgorria esan nahi zuten.

Esandakoaren arabera horiek birformulatzen hasita ere, zailtasunak topatzen ditugu (ii.a)rekin, pertsona horrek orban horiek izateak «ez baitzuen ezer esan nahi niretzat» (didn't mean anything to me). Hortaz, ez dago prik orban horiek esan nahi dutenik, eta ez dago prik, inplikatua izan den ala ez egiazta dezakegunik. Testa, beraz, aplikaezina da (ii.a)ren kasuan. Griceren adibide galduak, beraz, badu beste arazo hau ere: adibidearen lehen zatia desegokia da faktibotasun-testa pasatzeko ere. ${ }^{9}$

(ii.b)ren kasuan, ez dugu horrelako arazorik:

- Pertsona honek orban horiek izateak medikuarentzat pertsona horrek elgorria zeukala esan nahi zuen, baina ez zeukan elgorririk.

Eta egiazta daitekeenez, testaren aplikazioaren emaitza negatiboa da. Perpaus hori zuzena da erabat, eta kasu honetarako, beraz, ez da betetzen « $x \mathrm{k} p$ esan nahi du»k $p$ inplikatzen duela.

Hitz gutxitan esanda, faktibotasunaren testari erreparatuta, aplika dakiokeen neurrian, (ii) adibideak ez du balio. ${ }^{10}$ Eta Grice bera ere ohartuko zatekeen, testa aplikatu balio. Baina ez zion aplikatu; ez eta beste inolako test edo baldintzarik. Dena den, Gricek egin ez bazuen ere, interesgarria da ikustea goiko gainerako irizpideak aplikatuz gero zein emaitza lortzen dugun.

\section{Beste testak}

Faktibotasunaren ondoren, (2) baldintza dator:

(2) Ezin dut argudiorik osatu «Orban horiek elgorria esan nahi dute (zuten)»etik «orban horiek esan nahi dutena (zutena)»ri buruzko inolako ondoriotara iristeko; adibidez, ezin dezaket esan «orban hauek esan nahi zutena zen hark elgorria zuela». Era berean, azken aurre-

\footnotetext{
9 Eskerrak, beste behin, bigarren txostengileari, kontu honen garrantziaz ohartzeagatik.

10 Hemendik aurrera, (ii) adibidea aipatzen dugunean (ii.b)z ariko gara, bestelakorik esan ezean.
} 
kontuari buruzko goiko baiezpenetik ezin dut ondorioztatu «Azken aurrekontuak esan nahi duena da urte gogorra izango dugula». ${ }^{11}$

Kasu honetan, kontua ez da oso argia. Gure ustez, paragrafoak dioena ez da egia. Griceren arabera ondorioztatu ezin direnek erabat ondorioztagarriak ematen dute. Zer dago oker bi esaldi hauetan?

- Orban hauek esan nahi zutena zen hark elgorria zuela.

- Azken aurrekontuak esan nahi duena da urte gogorra izango dugula.

Ezer ez. Edo ez euskaraz behintzat. Agian hortxe egon daiteke arazoa kasu honetan: itzulpenean. Honela ageri dira perpaus horiek jatorrizko bertsioan:

- What was meant by those spots was that he had measles.

- What is meant by the recent budget is that we shall have a hard year.

Eta agian perpaus horiek erakusten dute ingelesez onargaitz bihurtzen dituen bitxikeriaren bat. Ez dakigu. Euskaraz, behintzat, ez diogu halakorik antzematen. Eta ezta (ii) adibideari aplikatzean ere:

- Orban horiek niretzat esan nahi zutena ez zen ezer. ${ }^{12}$

- Orban horiek medikuarentzat esan nahi zutena zen hark elgorria zuela.

Kasu honetan (ii) adibidea (i) eta (iii) bezain onargarria iruditzen zaigu euskarazko bertsioan. Eta ingelesez besteak bezain dudazkoa:

- What was meant by those spots to me was nothing.

- What was meant by those spots to the doctor was that he had measles.

Nolanahi ere den, (2) baldintza edo testaren balioa ez da begi-bistakoa gertatzen; batez ere, euskarazko bertsioan.

(3) eta (4) baldintzei dagokienez, aldiz, kontua argiagoa da. Hauxe diote banan-banan:

(3) Ezin dut argudiorik osatu «Orban horiek elgorria esan nahi dute»tik norbaitek orban horien bitartez hau-ta-hau esan nahi zuen moduko

11 Jatorrizkoa 3. oin-oharrean.

12 Perpaus hau gertatzen da, bai, arraro samarra, lehen aipatutako arrazoien antzekoengatik agian (eskerrik asko, bigarren txostengileari oharragatik). Hurrengoa, berriz, ez. Puntu honi dagokionez, dena den, ez da ondorioa aldatzen: zalantzazkoa da (ii)k (2) baldintza betetzen duen ala ez. 
inolako ondoriotara iristeko. Mutatis mutandis, gauza bera gertatzen da azken aurrekontuari buruzko perpausarekin.

(4) Goiko adibideetatik bat ere ezin da berregin «esan nahi» aditzaren aurretik komatxo arteko perpaus edo adierazpen bat daramala. Honela, «Orban horiek elgorria esan nahi zuten» ezin da birformulatu «Orban horiek 'elgorria' esan nahi zuten» edo «Orban horiek 'elgorria duela' esan nahi zuten» perpausen bidez. ${ }^{13}$

Gure adibide galduaren bigarren zatiari aplikatuta, horrela irakurriko genituzke inolako arazorik gabe:

— Ezin dut argudiorik osatu «Orban horiek medikuarentzat elgorria esan nahi dute»tik norbaitek orban horien bitartez hau-ta-hau esan nahi zuen moduko inolako ondoriotara iristeko.

— «Orban horiek medikuarentzat elgorria esan nahi zuten» ezin da birformulatu «Orban horiek medikuarentzat 'elgorria' esan nahi zuten» edo «Orban horiek medikuarentzat 'elgorria duela' esan nahi zuten» perpausen bidez.

Lehenengo zatiaren kasuan —hots, «orban horiek niretzat ez zuten ezer esan nahi» horretan-, lehen ere aipatutako arrazoiengatik, aldrebesxeagoak lirateke, baina emaitza bera izango genuke.

Eta, azkenik, honako hau da (5) baldintzaren hitzez hitzeko formulazioa:

(5) Bestalde, adibide hauek guztiak gutxi gorabehera berregin daitezke «...-elako gertakaria» adierazpena sartuz; adibidez, «Orban horiek zituelako gertakariak elgorria zuela esan nahi zuen» eta «Azken aurrekontua zen bezalakoa zelako gertakariak urte gogorra izango genuela esan nahi zuen». ${ }^{14}$

Azpimarragarria da, beste behin, «adibide hauek guztiak» esan arren, (ii) adibidea alde batera uzten duela hemen ere, eta beste adibideak darabiltzala soilik. Eta kasu honetan ere adibideak baldintza betetzen duela ematen du:

- Pertsona honek orban horiek zituelako gertakariak niretzat ez zuen ezer esan nahi.

- Pertsona honek orban horiek zituelako gertakariak medikuarentzat pertsona horrek elgorria zeukala esan nahi zuen.

\footnotetext{
13 Jatorrizkoa 3. oin-oharrean.

14 Jatorrizkoa 3. oin-oharrean.
} 
Kasu honetan, beraz, (ii) adibideak ere betetzen duela esan gabe joatea ulergarria eta kaltegabea izan liteke.

Orain artekoa laburtzeko: Gricek ez du behin ere erabiltzen hasieran ematen duen adibideen zerrendako bigarrena. Erabiliz gero, ikus daiteke, jartzen dituen bost baldintzetatik hiru (3-5) betetzen dituen arren, beste bat (2) betetzen duen zalantzazkoa dela (beste bi adibideen antzera, euskarazko bertsioan behintzat) eta beste bat (1) ez duela betetzen inondik ere. Eta, hain zuzen, betetzen ez duen hori -faktibotasuna- da bostetan garrantzitsuena. Beraz, nahikoa da hori adibide galduak artikulutik kanpo behar lukeela esateko.

\section{Nola liteke?}

Adibide galduaren kasuaz ohartu bezain laster sortzen den galdera da: nola liteke Grice bera ez ohartzea adibidearen zati batek ez duela bere testik garrantzitsuena betetzen eta lehen zatiari ezin zaiola aplikatu ere egin? Harrigarria gertatzen da benetan, batez ere, kontuan hartzen badugu oso gizon arduratsua eta zuhurra, perfekzionista omen zela, lanak publikatzerakoan. Ez zen, hasteko, oso argitaratu zalea. «Esanahia» bera bukatua omen zeukan 1948an egin zen Oxford Philosophical Societyren biltzar baterako, baina bere zalantza ohikoak tarteko, gordea zeukan, nonbait. ${ }^{15}$ Peter Strawson lagun filosofoak kezka omen zuen Oxfordeko filosofoek argitalpenetan presentzia txikia zutela, eta Grice konbentzitzen saiatu omen zen testua orraztu eta argitaratzeko bidal zezan, baina zegoenean bidaltzeko baimena izan zen lortu zuen bakarra. Hala, Ann emaztearekin batera testua txukundu eta, Gricek ez, haiek hartu zuten Philosophical Review aldizkari estatubatuarrera bidaltzeko eginkizuna (Chapman 2005: 63). Esan bezala, 1957an argitaratu zuen aldizkari horrek.

Strawson senar-emazteei ardurarik egotz liezaieke baten batek, baina ez litzateke oso zuzena. Gricerena da ardura, jakina. Harrigarria gertatzen da, hala ere, bai strawasondarrei, bai aldizkarian argitaratzeko erabakiaren parte izandako ebaluatzaile eta editoreei (ii) adibide galdua oharkabean pasatzea. Oso harrigarria.

Eta guk dakigula, behintzat, oharkabean pasatu zitzaien 1957az geroztik artikulua irakurri eta aztertu zuten garai hartako ehunka irakurleei ere. Azken hau ziurtatzeko modurik ez daukagu, bistan da. Baliteke guri ere oharkabean pasatu izana aurkikuntza, propio egindako gure irakurketetan. Kontua

\footnotetext{
15 Bere lanik ezagunena ere, «Logic and Conversation», 1967an AEBetan emandako hitzaldietan aurkeztu zuen eta bertsio idatziak zabaldu ziren zirkuitu zabal batean. 1975ean argitaratu zen, eta bi bildumatan argitaratu ere urte berean. Zortzi urte argitaratu gabe egotea ez zen izan, beraz, argitaratzaile faltagatik, bere erabakimen ezagatik baizik. Geroztik, hizkuntzaren filosofia eta pragmatikako bilduma guztietan argitaratu dute; eta, 1989an, Gricek berak atondutako bilduman. Ez zuen bilduma kalean ikusi, ordea, 1988an hil baitzen.
} 
da, inork inoiz deskuidu bikoitza identifikatu bazuen ere, ez ziola Griceri jakinarazi. Edo ez ziola Gricek jaramonik egin, behinik behin. Hala erakusten dute honako bi gertaera hauek: 1982an «Meaning Revisited» argitaratu zuen, «Esanahia» artikulua aipagai duena, eta ez dago nahastearen zuzenketa-aztarnarik, inondik ere; eta, oraindik argiagoa dena, hil aurretik prest utzi zuen bilduman (Grice 1989), hainbat lanen bertsio berriak prestatu arren, ez zuen «Esanahia» ukitu, ${ }^{16}$ eta deskuiduak bere horretan jarraitu zuen: (ii) adibideak bere tokian segitzen du, ez du ondoren ezertarako erabiltzen eta, jakina, testa aplika dakiokeen neurrian, ez du faktibotasunaren baldintza betetzen. Grice ez zen nahasteaz ohartu, edo ez zitzaion iruditu zuzentzea merezi zuenik. Azken hau oso zalantzazkoa da, dena den, bere izaera perfekzionista dela eta. ${ }^{17}$

Horrez gain, galdera bera egin daiteke 1957tik aurrera eta 1989ko berrargitalpenetik aurrera izandako ehunka irakurle eta ikertzaileei buruz: nola liteke? Griceren «Esanahia»ren berri ematen duten lan nagusiek ere nahastea errepikatzen dute. Chapmanek (2005), esate baterako, (i) eta (iii) adibideak aipatzen ditu soilik, eta faktibotasuna azpimarratzen esanahi naturaleko adibideen ezaugarri gisa. Nola liteke? Ez zaigu erantzun sinesgarririk bururatzen. Adibideak galduta segitu du urte askoan. Orain arte.

Beste galdera bat ere bururatzen zaigu: zein da nahastearen garrantzia?

\section{Adibide galduaren garrantzia}

Puntu honetara iritsita, argi behar luke gure aurkikuntzak eta bere izaera historikoak. Garrantzi kontzeptuala ez dago, agian, horren argi. Gricek ez du (ii) behin ere erabiltzen eta adibideak ez du faktibotasun-baldintza betetzen, ez, eta zalantzazkoa da (2) baldintza betetzen duen ere. "Grice nahastu egin zen, bai; eta zer?», galde dezake norbaitek. Hauxe da gure erantzuna.

(ii) adibideak faktibotasun-baldintza ez betetzeak agerian uzten du Gricek ez duela ongi egiten esanahi naturalaren eta ez-naturalaren arteko bereizketa. Artikuluan Gricek berak argudiatzen duenez, zeinu naturalaren eta

16 1989ko edizioan atzematen dira beste zuzenketa batzuk, ordea. Esanahi ez-naturalez emandako lehen adibidean, esaterako, «bus is full» hitzak komatxo sinpleen artean daude, 1957an argitaratutako jatorrizko bertsioan. Okerra zuzendua dago 1989koan, baina hizkuntzaren filosofiako irakurgai-bildumetan akatsa errepikatu izan da. Martinichen (1985) bilduma ezagunean, esate baterako, hala egin dute lehen bi argitalpenetan (1985 eta 1990ekoan, hurrenez hurren). Hirugarrenetik aurrera (1996) azaltzen da oker hori zuzenduta.

17 Adibide oker eta galduari buruz diogunaren oinarria sendotzeko, baliagarri izango litzaizkiguke Berkeleyko Bancroft liburutegian gordetzen dituzten argitaratu gabeko Griceren lanak eta oharrak; eta, bereziki, «Meaning» idatzi zuen garai bertsuko «Dispositions and Intentions» eta «Lectures on Peirce». Beste baterako utzi dugu, halabeharrez, lan hauen kontsulta. 
konbentzionalaren arteko bereizketa baino egokiagoa izan liteke, baina badirudi badela gaizki dagoen zerbait bereizketa berrian. Zer, ordea?

Pentsa liteke ematen dituen bost baldintzetan (eta horiei kontrajartzen dizkien beste bostetan) dagoela arazoa. Azken finean, baldintza intuitiboak dira, (ingelesezko) hainbat perpausen onargarritasun edo onartezintasunari buruzko intuizioetan oinarritutakoak, Oxforden garai haietan ernaltzen ari zen hizkuntza arruntaren filosofiaren metodoei jarraiki. Ezartzen dituen baldintzak eta, bereziki, faktibotasunarena, berrikusi eta findu beharra dagoela erakusten du, hasteko, adibide galduaren kasuak.

Faktibotasuna berrikusi egin behar da, bai, baina, Griceri jarraiki, ezin da besterik gabe baztertu baldintza hori. Ez lehena delako bakarrik, baizik eta, «Meaning Revisited»en egiten duen aipamenean ikus daitekeen bezala, garrantzitsuena delako. Ikusi dugun bezala, dagoenean ere, faktibotasunaren forma orokorrak berrikuspena eskatzen du adibideei behar bezala aplikatzeko:

— $x \mathrm{k} p$ esan nahi zuenek eta $x \mathrm{k} p$ esan nahi duk $p$ inplikatzen dute

dio forma horrek. Goian adierazi bezala, esanahia —naturala nahiz ez-naturala- daukan gertaera, egoera edo ekintza (esaldi bat barne) izan behar du $x \mathrm{k}$. Gure adibideak, ordea, «orban horiek» dio: une jakin batean, toki jakin batean, pertsona jakin batek zeuzkan orban horiexek; eta gauza bera esan dezakegu Griceren adibideetan xren tokian agertzen diren adierazpen guztiei buruz; hau da, «azken aurrekontuak», «txirrinaren hiru joaldi horiek» edo «ohar horrek» adierazpenei buruz.

Kontua argiago dago pri buruz: modu proposizionalean adieraz daitekeen $x$ ren esanahiari dagokio. Eta faktibotasun-testak balio behar luke bereizteko esan nahi du (zuen) aditzaren bi zentzuak: naturala eta ez-naturala. (i) adibideak betetzen du; (ii)k ez. Hurrenez hurren, (i') eta (ii.b') birformulatuei aplikatuta,

— «Pertsona honek orban horiek izateak $(x)$ esan nahi du pertsona honek elgorria daukala $(p) » \mathrm{k}$ inplikatzen $\mathrm{du}$ «pertsona honek elgorria dauka» $(p)$.

— «Pertsona honek orban horiek izateak $(x)$ medikuarentzat esan nahi zuen pertsona horrek elgorria zeukala $(p) » k$ ez du inplikatzen «pertsona honek elgorria dauka» $(p)$.

Emaitza horri erreparatuta, (ii) ez litzateke esanahi naturalaren adibidea, baina esanahi ez-naturalaren kasutzat hartzeak ere ez dirudi arrazoizkoa, hala ere. Adibide honek faktibotasun-testean huts egitearen iturria oso argi dagoela erakusten du. Alde txikia baina erabakigarria daukate (ii) adibideko 
bi perpausek eta (i) adibidekoak: (ii) adibidean, hurrenez hurren, «niretzat» eta «medikuarentzat» sartzeak esanahia agente batekiko erlatibo bihurtzen du, faktibotasuna desagerrarazi arte.

Bestalde, arazoa orain arte uste izan duguna baino zabalagoa izan liteke. (iii) adibideari beste begiratu bat emanda ere, ez dirudi faktibotasuna hertsiki betetzen duenik. Aurtengo aurrekontuak urte gogorra izango dugula esan nahi duela egiazkoa izanda ere, horrek ez du logikoki inplikatzen gure urtea gogorra izango denik nahitaez. Aurrekontua dela eta, probabilitate handia egon daiteke urte gogorra izateko, baina probabilitate handia ez da inplikazio logikoa. «Meaning Revisited»eko (vi) eta (vii) adibideak birpentsatzen baditugu ere, nahikoa argi dago tartean probabilitatea dagoela, ez inplikazio logikoa, ezta fisikoa ere: «hodei beltz haiek euria egingo zuela esan nahi zuten, bai, baina haizearen indarrak euria eragotzi du». Ez dirudi ezer absurdorik dagoenik horretan. ${ }^{18}$

Bi aukera planteatzen zaizkigu horren aurrean. (ii) eta (iii) adibideek, eta «Meaning Revisited»eko (vi)k eta (vii)k, ez dute faktibotasuna betetzen. Beraz, bietako bat: ez dira esanahi naturalaren kasuen adibideak edo, bestela, faktibotasuna ez da natural izateko bete beharreko baldintza. Guk bigarren bidea dugu nahiago. Adibide horiek esanahi naturaleko kasuak dira, baina emaitza desberdinak dauzkate faktibotasun-testa eta besteak pasatzen dizkiegunean. Hortaz, esanahi naturalaren barruan hainbat kasu mota bereiz daiteke, test horiek erabilita ere. Esan genezake horretan ez dugula bat egiten Gricerekin; baina ez dago horren argi. Izan ere, beste behin, Grice zuhurra da testaz hitz egitean. Testa, bere hitzetan:

... gutxi gorabehera esanda, esanahiaren kasu ez-naturalak, komunikazioari lotutako kasuak direnak, ez-faktiboak dei genitzakeenak direla, eta, kasu naturalak, ordea, faktiboak direla. «Hodei beltz horiek euria esan nahi dute», edo «Hodei beltz horiek esan nahi zuten euria egingo zuela» esaten duen edonork, seguru asko, konpromisoa hartuko lukeela euria egingo duela edo euria egin zuela gertakaria izatearekin. (Grice 1989 [1982]: 291. Letra etzanak gureak) ${ }^{19}$

18 Bigarren txostengileak adierazi digun bezala, arraroa gerta liteke esatea «Hodei horiek euria egingo zuela esan nahi zuten, baina ez zuen euririk egin». Eta bat gatoz harekin normalean «esan nahi» erabili gabe birformulatuko genukeela. Baina kontua ez da modu egokiago eta naturalagoren bat aurki dezakegun hori esateko euskaraz. Kontua da euskaraz hori esatea absurdoa den ala ez. Eta uste dugu guk jarritako adibidea behintzat egokia dela. Edo har beste hau: «Gaurko itsasoko ekaitzak malekoiko tabernen hondamendia esan nahi zuen, baina herritarrek eragotzi egin dute. Lokalak behar bezala babestu eta ez da hondamendirik izan». Esaldia birformula daiteke eta «iragarri» edo erabili «esan nahi»ren ordez; baina, dagoenean ere, naturala egiten zaigu guri.

19 ... roughly speaking, that the nonnatural cases of meaning, cases which are related to communication are what we might call nonfactive, whereas the natural cases are factive. That is anyone who says «Those black clouds mean rain,» or «Those black clouds meant that it would rain,» would presumably be committing himself to its being the case that it will rain, or that it did rain (Grice 1989 [1982]: 291). 
«Gutxi gorabehera esanda» (roughly speaking) eta «seguru asko» (presumably) horiek nahikoa argi adierazten dute Gricek bidea uzten diola faktibotasun-testaren aplikazio malgu bati. Malgutasun horren nondik norakoa zehazte aldera, interesgarria izan liteke bide berriak jorratzea.

Esate baterako, Griceren esanahi naturalaren faktibotasunaren atzean bi gertaeren arteko lotura probabilistikoaren gisako zerbait dagoela esan daiteke. ${ }^{20}$ Orban horren presentziak oso litekeena egiten du (erabat ziurra agian) gaixoak elgorria izatea; aurrekontu horrek litekeena egiten du oso (baina ez nahitaezkoa) datorrena urte gogorra izatea; hodei beltz horien presentziak euria egiteko arrisku (probabilitate) handia dakar berarekin (ez erabatekoa, hala ere).

Oker ez bagaude, kasu batzuetan faktibotasunaz hitz egiten denean, inplikazioaz ez, probabilitate-gradu handiaz hitz egin beharko litzateke. Eta, akaso, esanahi naturalaren kasu batzuetan, ez litzateke baztertu behar probabilitate-gradu txikiko loturak ere izatea. Azterketa sakonagoa behar du, azken aukera horrek, batez ere. Dena den, gure ustez, Griceren bereizketa nagusia (esanahi naturalaren eta ez-naturalaren artekoa, alegia) ez da oinarritzen lotura horren existentzian ala gabezian. Esanahi ez-naturalaren kasua agente baten ekintzaren asmoari, intentzioari lotua dago. Horretan bat egiten dugu Gricerekin. Kasu horretan, esanahi naturalaren kasuan ez bezala, esalearen zintzotasunik ezarako aukera dago. Hori da bereizketaren giltza. Baina hau, gai garrantzitsua izanagatik, ez da lan honen gaia.

\section{Ondorioak}

Bukatzeko, esan dezagun, beste behin, hainbat urtetan oharkabean pasatutako gertaera historiko harrigarri baten berri ematea izan dela gure helburu nagusia. Gertaeraren garrantzi historikoa ukaezina da. Gricek deskuidua izan zuen argitaratutako lehen lanean, edo hori uste dugu, eta ez berak, ez ingurukoek (strawsondarrek bereziki) ez zuten horretan erreparatu. Guk esan dezakegunaren arabera, ez berak ez filosofia eta hizkuntzalaritzako ehunka ikertzailek erreparatu diote gerora nahaste horri. Sinesgaitz egiten zaigu guri ere, baina, guk dakigula, lehen aldia da nahastea plazaratzen dena.

Garrantzi kontzeptualari dagokionez, ondorioztatu dugu faktibotasunak ez duela balio, hertsiki hartuta behinik behin, esanahi naturalaren eta ez-naturalaren kategorien arteko muga ezartzeko. Esanahi naturaleko kasuen kategorian, gainera, kontua ez da beharrezkotasun logikoa, fisikoa edo metafisi-

\footnotetext{
20 Azken eztabaidak eta, bereziki, iradokizun honek asko zor diete Stephen Nealeren «Means, means, means» (Dubrovnik, Kroazia, 2018ko iraila; Donostia, 2019ko maiatza) hitzaldiei eta artikulu honen lehen egileak Nealerekin berarekin izandako elkarrizketei.
} 
koa. Agian probabilitate-gradu ezberdinetako gertaeren arteko harremana da esanahi naturalaren kasuan dagoena; intentzioa, berriz, esanahi ez-naturalaren kasuan.

Nolanahi ere den, esanahi ez-naturalari buruzko azalpena izan zen Griceren ekarpen nagusia «Esanahia» lanean, eta bertan egiten duen hiztunaren asmoan oinarritutako karakterizazioak ez du batere baliorik galdu, deskuiduak deskuidu.

\section{Erreferentziak}

Chapman, Siobhan (2005), Paul Grice, Philosopher and Linguist. London: Palgrave Macmillan.

DenKel, Arda (1992), «Natural Meaning». Australasian Journal of Philosophy 70 (3): 296306. DOI: 10.1080/00048409212345191

Grice, H. Paul (1957), «Meaning». The Philosophical Review 66 (3): 377-88. In Grice (1989) berrargitaratua: 213-23. Euskarazko itzulpena, Kepa Kortarena, in Korta (arg.) (2007): 145-55.

Grice, H. Paul (1967), «Logic and Conversation». In D. Davidson \& G. Harman (arg.) 1975, The Logic of Grammar. Encino: Dickenson, 64-75. Baita ere in P. Cole \& J. L. Morgan (arg.) 1975, Syntax and Semantics 3: Speech Acts, New York: Academic Press, 41-58. In Grice (1989)n berrargitaratua: 22-40.

Grice, H. Paul (1968), «Utterer's Meaning, Sentence-Meaning and Word-Meaning». Foundation of Language 4 (3): 225-42. Grice (1989)n berrargitaratua: 117-37.

Grice, H. Paul (1982), «Meaning Revisited». In N. SMith (arg.), Mutual knowledge. London: Academic Press. Grice (1989)n berrargitaratua: 283-303.

Grice, H. Paul (1989), Studies in the Way of Words. Cambridge: Harvard University Press.

KorTA, Kepa (arg.) (2007), Hitzaren Lilura. Hizkuntzaren Filosofiako Irakurgaiak. Bilbo: UPV/EHU.

Martinich, Aloysius P. (1985), The Philosophy of Language. Oxford: Oxford University Press.

Stevenson, Charles L. (1944), Ethics and Language. New Haven: Yale University Press. 